\title{
Resource Approach to the Estimation of International Cooperation in Integrated Development of Calciphyre Deposits
}

\author{
Kamkicheva Olga N. ${ }^{\text {a }}$, Voznaya Anna A. ${ }^{\text {b }}$, Mikhailova Tatyana V. ${ }^{c}$, Gribanova Galya I. ${ }^{\text {d }}$ \\ T. F. Gorbachev Kuzbass State Technical University \\ Kemerovo, Russian Federation \\ a kon.geo@kuzstu.ru, ${ }^{\mathrm{b}}$ vaa.geo@kuzstu.ru, ${ }^{\mathrm{c}}$ mtv238@mail.ru, ${ }^{\mathrm{d}}$ ggi.geo@kuzstu.ru
}

\begin{abstract}
Deposits of precious corundum are very rare, since the transparent crystals can be formed only under favorable growth conditions. The most important core sources of precious corundum are marble with ruby mineralization and sapphire-containing basalts. The scholars of T.F. Gorbachev Kuzbass State Technical University in cooperation with Kyrgyz partners initiated the research of corundum-containing calciphyre deposit Ormizan, which results would allow implementing of the integrate development of corundum and some very valuable minerals - titanium, manganese, magnesium etc. The article aims at determination of the possibility of passing extraction of high value and rare and earth metals under industrial mining calciphyre, as well as to outline the ways of international cooperation of mining companies and enterprises in this area.
\end{abstract}

Keywords - Calciphyre, corundum, cooperation, mineral deposits, integral development

\section{INTRODUCTION}

Currently, extractive industries are a major source of jobs, fiscal revenues, GDP for most countries of the former USSR $[1,2]$. Both national and international companies are involved in the recovery of many types of natural resources [3, 4]. Integrated development of especially valuable minerals (rare and rare-earth metals, jewels) requires state support and establishing of international cooperation $[5,6]$. Therefore, the geology today is entrusted with the important task of determining the resource base of integrated recovery of strategic important minerals.

\section{SUBJECT OF RESEARCH}

Calciphyre is the host rock for the valuable mineral - corundum (aluminum crystalline $\alpha$-oxide). Commonly calciphyre is companion for the forecast of closely spaced deposits of rocks, containing highly valuable elements, such as titanium, manganese, magnesium.

We attempted to make a preliminary research of integrated development of the main mineral (calciphyre) and accompanying raw materials. For this purpose, we plotted a graph determining the acceptance level of calciphyre deposit development with various contents of certain components (Fig. 1).
From Fig. 1 follows that entire calciphyre deposit can be divided into 4 zones:

I - the most favorable zone for development of deposit, including both calciphyre and simultaneously extracted raw material - manganese, titanium, aluminum oxide, magnesium.

II - moderately favorable zone - calciphyre deposit rich with corundum.

III - less favorable zone - the segment with accompanying extraction of valuable minerals with high concentrations.

IV - the least favorable zone - the deposit of accompanying extraction of valuable minerals with low concentrations.

To determine the level of favorability of deposit Ormizan for integrated development it is necessary to consider its geological structure. In geological structure of Ormizan deposits Paleozoic and Quaternary formations took part. Paleozoic complex is represented with calciphyres and schists, quartzites (S2-Dms).

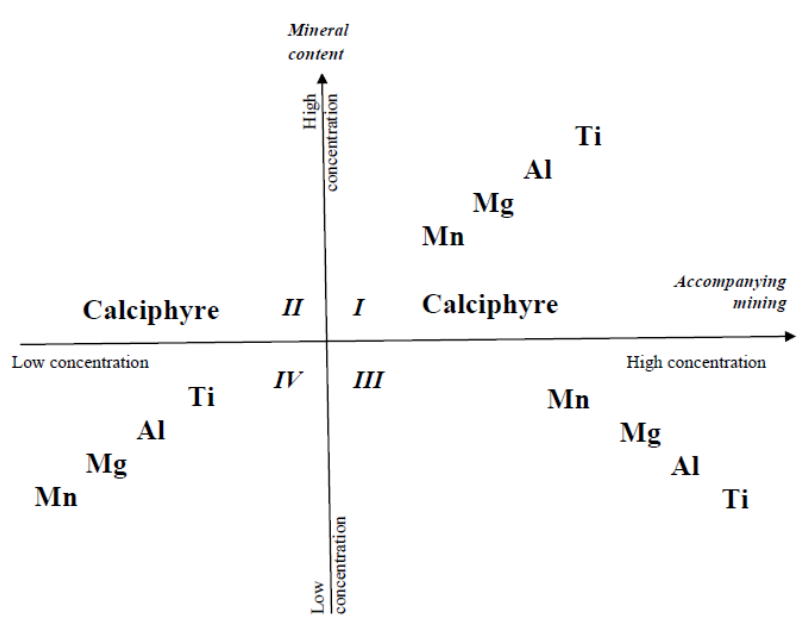

Figure 1. Graph of the estimation of acceptance level of calciphyre deposits for integrated development

The analysis of ecological problems of mineral deposits development as well as the research of innovative machinery for complex mineral deposits development [13] were con- 
ducted in T.F. Gorbachev Kuzbass State Technical University [7-12].

\section{MATERIALS AND METHODS}

The study of rocks and minerals of Ormizan deposit required using the following methods: petrographic description of rocks, mass spectrometry with inductively coupled plasma, luminescence analysis, and microanalysis. Laboratory studies were conducted on the basis of commonly used united center "The analytical center of natural systems geochemistry" of Geology and Geography Department, National Research Tomsk State University.

During our research we defined that the Ormizan deposit is composed of calciphyre which is white and light gray in color, and it has a complex zonal and zonal-block structure.

Analysis of the distribution of rare and rare earth elements in calciphyre deposit Ormizan described in this article was conducted for the first time. For the zonal area I and II we defined an increase in the concentration of $\mathrm{Ti}, \mathrm{Sc}, \mathrm{V}, \mathrm{Ta}, \mathrm{Zr}$, $\mathrm{Nb}, \mathrm{U}$, Th and deficit $\mathrm{Co}, \mathrm{Ni}, \mathrm{Mn}$ relative to chondrite [1417]. We observe a clear change in the concentrations of a number of rare and trace elements in selected petrotypes (Fig. 2) which is connected with the presence of isomorphcontaining kinds, such as pomegranate, phlogopite.

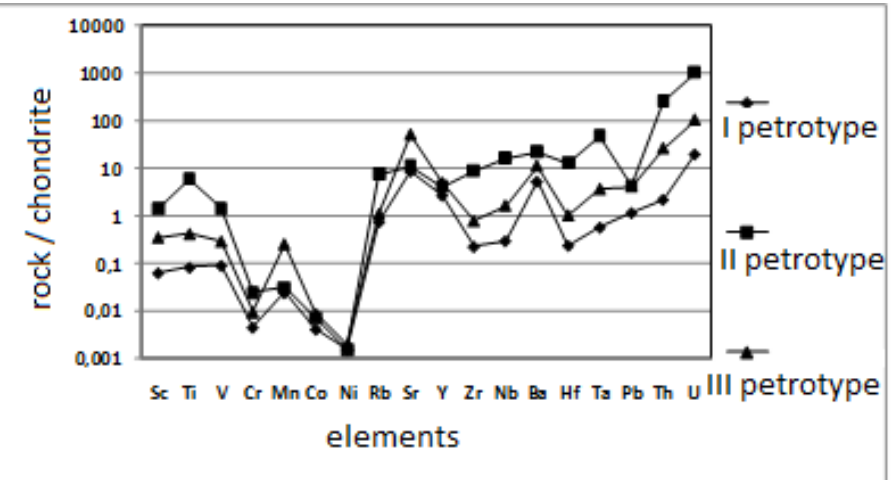

Figure 2. Spider diagram of rare and traced elements in calciphyre from Ormizan deposit, rated on chondrite

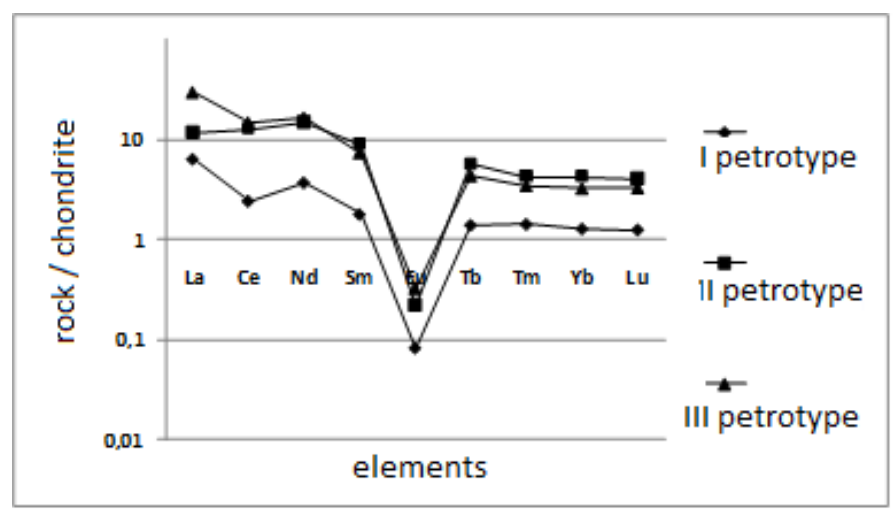

Figure 3. Spider diagram of rare earth elements in calciphyre from Ormizan deposit, rated on chondrite
The distribution pattern of rare earth elements in calciphyre indicates the single protolith involved in the formation of metamorphic rocks. The regular change of summed amount of rare earth content in petrotypes may be associated with changes in PT-conditions of calciphyre formation (Fig. 3 ). Eu anomaly is traced in selected petrotypes, which indicates a high-temperature process of regional metamorphism [18-21].

Corundum timed to zonal areas I and II of Ormizan deposit and forms isolated crystals in calcite, associated with phlogopite, graphite and pyrite. The shape of the types is barrel-shaped, improper shaped with size up to $1 \mathrm{~cm}$. The predominant color is pink-and-purple-and-red, less often white, yellow and gray of its species. The central parts of crystals usually intensively raspberry colored. Large clusters are generally fractured, have a well-defined separation and include multiple grains at the edges substituted by boehmite in varying degree.

\section{RESULTS}

The fluorescent emission spectrum of corundum has a pronounced peak in the range of $680-700 \mathrm{~nm}$, which is caused by the entry of isomorphic adulteration $\mathrm{Cr}+3$ in the crystalline structure of the mineral (Fig. 4). It is known that the isomorphism in the system $\mathrm{Al}-\mathrm{Cr}$ is directly dependent on the mineralization temperature. Thus, the occurrence of $\mathrm{Cr}+3$ in corundum structure may indicate a medium- and hightemperature facies of regional metamorphism.

The luminescence spectrum of calcite is characterized by a wide maximum of 600-620 nm due to the presence of structural adulteration $\mathrm{Mn}+2$. It should be noted that for calcite of calciphyre with corundum mineralization the luminescence intensity is much lower than for calcite of zone-block area that does not contain corundum. The resulting luminescence spectra are identical to the curves of the luminescence of calcite from Kuhi - Lal precious spinel deposits. Thus, the luminescence of metamorphic genesis calcite with corundum and spinel mineralization is identical.

\section{DISCUSSION}

The typochemism of a number of minerals that are present in calciphyre, allows us to get unique information about the environment of mineralization.

The chemical composition of mineral deposits Ormizan is shown in Table 1.

Thus, the following typochemical characteristics of the secondary and accessory minerals deposits have been received:

1. Vesuvianite from Ormizan deposit is nonstoichiometric in $\mathrm{X}$ position (calcium deficiency), the titanium content sometimes reaches $4.7 \%$, allowing it to be attributed to the titanium - vesuvianites. 


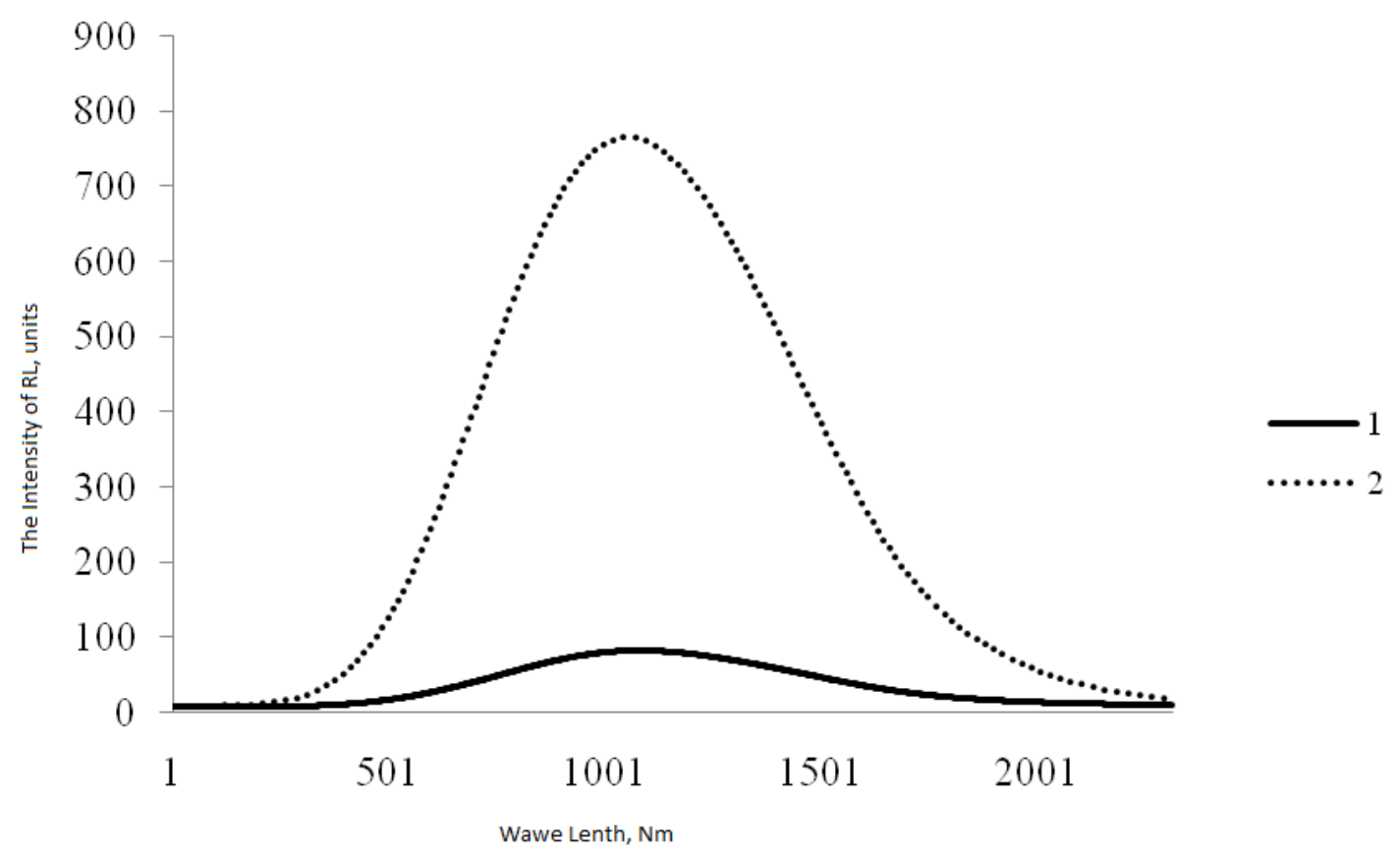

Figure 4. Specters of Roentgen luminescence of calcite from Ormizan deposit. 1 - calcite without corundum mineralization; 2 - calcite with corundum mineralization

TABLE 1. CHEMICAL COMPOSITION OF THE MINERALS FROM CALCIPHYRE OF ORMIZAN DEPOSIT CORUNDUM (WEIGHT \%)

\begin{tabular}{|l|l|l|l|l|l|l|l|l|l|l|}
\hline Oxides & $\mathrm{SiO}_{2}$ & $\mathrm{TiO}_{2}$ & $\mathrm{Al}_{2} \mathrm{O}_{3}$ & $\mathrm{FeO}$ & $\mathrm{MnO}$ & $\mathrm{MgO}$ & $\mathrm{CaO}$ & $\mathrm{K}_{2} \mathrm{O}$ & $\mathrm{Na}_{2} \mathrm{O}$ & $\mathrm{F}$ \\
\hline Vesuvianite & $36.79-$ & $4.69-$ & $15.26-$ & $3.39-$ & $0.01-$ & $1.57-$ & $35.70-$ & 0.00 & 0.00 & $1.34-$ \\
& 37.19 & 5.08 & 15.60 & 3.52 & 0.10 & 1.62 & 35.90 & & & 1.36 \\
\hline Garnet & $39.09-$ & $0.25-$ & $20.11-$ & $5.46-$ & $0.14-$ & $0.29-$ & $34.28-$ & 0.00 & 0.00 & 0.00 \\
& 39.18 & 0.31 & 20.20 & 5.60 & 0.22 & 0.32 & 34.47 & & & \\
\hline Amphibolite & $42.01-$ & $1.66-$ & $17.09-$ & $1.11-$ & 0.00 & $16.19-$ & $13.86-$ & 0.00 & $\begin{array}{l}2.45- \\
2.99\end{array}$ & $1.01-$ \\
& 44.02 & 1.94 & 18.67 & 1.43 & & 16.79 & 14.11 & & 1.63 \\
\hline Pyroxene & $55.34-$ & 0.00 & $0.62-$ & $2.14-$ & 0.00 & $15.01-$ & $25.95-$ & 0.94 & 0.00 & 0.00 \\
& 55.82 & & 0.91 & 2.16 & & 15.17 & 25.98 & & & \\
\hline Mica & $40.17-$ & $1.04-$ & $17.17-$ & $0.51-$ & 0.00 & $26.26-$ & 0.00 & $9.99-$ & $0.79-$ & $1.28-$ \\
& 42.54 & 1.23 & 19.33 & 0.67 & & 26.94 & & 10.26 & 0.87 & 1.69 \\
\hline
\end{tabular}

2. Garnet refers to grossularite-andradite row with a small adulteration of almandine (4-6\%) and pyrope (2-3\%) of molecules, which are generally typical for garnets from marbles and calciphyre of other deposits. Featured grossularite Ormizan field, should be considered as titanium impurity.

3. The chemical composition of amphibole can be attributed to the hornblende with a small adulteration of kaersutite, fluorine content ranges from $1 \%$ to $1.5 \%$. It should be noted that the amphibole from Ormizan deposit is characterized by an increased content of $\mathrm{Ti}, \mathrm{Al}, \mathrm{F}$, unlike amphibole from marble and calciphyre of other regions.

4. The chemical composition of the diopside from calciphyres of Ormizan deposits is similar to the chemical composition of the diopside from the other marbles different in met- amorphic and meta-somatic genesis. A small amount of Mn causes the presence of iogansenit molecule that can be considered as a typomorphic sign of diopside from Ormizan deposit.

5. Mica on the content of $\mathrm{Mg}, \mathrm{Fe}, \mathrm{Al}$ refers to phlogopite of series phlogopite-eastonite, as muscovite is about $10-15 \%$. The presence of isomorphic adulteration of $\mathrm{Ti}$ in the composition of mica can be regarded as his typochemical feature. The chemical composition of mica from the other metamorphic deposits with semi-precious mineralization is not different from phlogopite of Ormizan deposit composition.

Consequently, the Ormizan deposit completely satisfies the set of characteristics of I-th segment in the proposed approach (Fig. 1). So we made the following statements: 
- Carbonate rocks are located in synclinal structures determined by the geological situation of Ormizan. The level of metamorphism corresponds to the amphibolite facies and is determined by the presence of wollastonite, diopside, feldspar in calciphyre;

- In the observed area there are granitoid intrusions that define corundum mineralization of calciphyre;

- Recrystallization of carbonate rocks takes place with the fluid participation, as indicated by the increased content of $F$ in mica, amphibole, vesuvianite;

- mineral corundum satellites are phlogopite, graphite, pyrite, wollastonite, quartz, pyroxene, hornblende, idocrase, sphene.

The study of typomorphic features of calciphyre showed the presence of $\mathrm{Mn}+2$ adulteration in the calcite structure. For typical vesuvianite increased titanium content (up to 5\%) is common. The presence of $\mathrm{Ti}$ in the mineral composition causes an orange-and-red color. Typomorphic feature of garnet is the presence of pyrope (2-3\%) and almandine (4-6\%). Also micro- adulteration of Ti is typochemical feature of grenade from the Ormizan deposit. For amphibole the presence of titanium and iron is typical, which leads to a honey-andyellow color of hornblende. Clinopyroxene can be characterized by the content of magnesium $(15.1 \%)$ and calcium $(25.9 \%)$ and a small adulteration of Mn. Roentgen luminescence of corundum showed the presence of $\mathrm{Cr}+3$ adulteration.

The presence of high content of $\mathrm{Mn}, \mathrm{Al}$ in the composition of vesuvianite, grenade, phlogopite, and $\mathrm{Ti}, \mathrm{Cr}$ in corundum, and $\mathrm{V}$ in the studied minerals point on participation in calciphyre formation of 2 contrast medias. The first elements $(\mathrm{Al}, \mathrm{Mn})$ are components of acid and the rocks similar in composition, and the second ( $\mathrm{Ti}, \mathrm{Cr}, \mathrm{V})$ are elements of basic rocks. The presence of $\mathrm{Mn}$ adulteration in the composition of rock-forming and accessory minerals indicates the restoring conditions of mineralization.

\section{CONCLUSIONS}

Thus, one of the prediction criteria for semi-precious mineralization searching in calciphyre for integrated development of calciphyre deposits is the presence of titanium, magnesium, manganese, aluminum in rock-forming and secondary minerals.

\section{ACKNOWLEDGEMENTS}

The authors express their gratitude to the staff of Open Pit Mining Department of the T.F. Gorbachev Kuzbass State Technical University. The authors also express their sincere appreciation and gratitude to O.I. Litvin for his significant personal involvement and support.

\section{REFERENCES}

[1] Zhironkin S.A. Governmental factoring development of TEK Kuzbass Ugol', 2001, vol. 6, pp. 62.

[2] Zhironkin S.A. Prospects and new possibilities investment attracting to Kuzbass coal mining industry. Ugol', 2002, vol. 6, pp. 31-36.

[3] Zhironkin S.A. Factoring and leasing development at coal mining industry of Kuzbass as an important element of its financial part. Ugol', 2001, vol. 4, pp. 29-30.

[4] Zhironkin S.A. About measures of vexel circulation development and vexelability definition of fuel-and-power complex' enterprises. Ugol', 2002, vol. 4, pp. 47-48.

[5] Barysheva G.A., and Novoselova E.G. Methodology of Application of the Structural Shift Mechanism for Regulation of the National Economic Management System. Applied Mechanics and Materials. 2014, Vol. 682, pp. 550-554

[6] Gasanov M., Gasanov E., and Egorova M. The Technologies of the Network Prosperity in Russia. Procedia - Social and Behavioral Sciences, 2016, vol. 166, pp. 103-106

[7] Lesin Y.V., Lukyanova S.Y., and Tyulenev M.A. Mass transfer of dispersed particles in water filtration in macro-grained media. Journal of Mining Science, 2010, vol.46-1, pp. 78-81.

[8] Zhironkin S.A., Tyulenev M.A., Zhironkina O.V., and Hellmer M. The global determinants of mining higher education development. Metallurgical and Mining Industry, 2016, vol. 2, pp. 62-67.

[9] Tyulenev M.A. and Lesin Y.V. Justification complex purification technology open-pit mines wastewater. Taishan: Academic Forum Project on Mine Disaster Prevention and Control, 2014, pp. 441-444.

[10] Lesin Y.V., Luk'yanova S.Y., and Tyulenev M.A. Formation of the composition and properties of dumps on the open-pit mines of Kuzbass. IOP Conference Series: Materials Science and Engineering, 2015, vol. 91(1), 012093.

[11] Tyulenev M, Zhironkin S., and Litvin O. The low-cost technology of quarry water purifying using the artificial filters of overburden rock. Pollution Research, 2015, vol. 34 (4).: pp 825-830.

[12] Tyulenev M., Lesin Y., Zhironkin S. and Garina E. Coal producers waste water purification. Metallurgical and Mining Industry. 2016, Vol. 2, pp. 52-56.

[13] Khoreshok A. On side cutting bit when operating at sheerer drums Ugol', 2002, vol. 7, pp. 10-11.

[14] Sobolev N.V. Polugenez mineralov [Paragenic types of garnet]. Moscow: The Science, 1964, 219 p.

[15] Kievlenko R.Ya. Geologiya zalezhey dragocennikh mineralov [The geology of jewelry deposits]. Moscow: Nedra, 1982, 279 p.

[16] Kisin A.Yu. Zalezhi rubinov v mramorakh Urala [Rubi deposits in marbles of Urals]. Sverdlovsk: URORAN, 1991, 125 p.

[17] Gorodovikov A.A. Mineralogiya [The Mineralogy]. Moscow: Nedra, $1970,520 \mathrm{p}$.

[18] Chernishova L.V. Tipomorfizm minaralov [Typomorphism of minerals]. Moscow: Nedra, 1989, 560 p

[19] Sclyarov E.V. Intepretacia geokhemicheslikh dannikh [Geochemical data interpretation]. Moscow: Intermet, 2001, 288 p.

[20] Gorobets B.S. Spectri luminiscencii mineralov [The specters of minerals luminescence]. Moscow, VIMS, 2001, 312 p.

[21] Melchers, K., Kretschmann Yu., Goerke-Mallet P., Kleineberg K., and Tyulenev M. Elementy i aspekty post-ekspluatatsionnogo perioda gornykh predpriyatij [Elements and aspects of post-operational period of mining enterprizes]. Vestnik Kuzbass. gosud. tehn. univ., 2015, vol. 6 , pp. 3-13. 